DOI: $10.5937 /$ SustFor2183027P

Original scientific paper

\title{
VARIABILITY OF HUNGARIAN OAK (Quercus frainetto Ten.) FROM THE TERRITORY OF LIPOVICA ACCORDING TO MORPHOLOGICAL TRAITS OF SEEDLINGS
}

\author{
Vladan POPOVIĆl, Aleksandar LUČIĆ ${ }^{l}$, Ljubinko RAKONJAC ${ }^{l}$, \\ Sanja JOVANOVIĆ , Ivica LAZAREVIĆ ${ }^{2}$
}

\begin{abstract}
Natural populations of Hungarian oak in Serbia are found near the northwestern boundary of the range of distribution of this significant forest species. The survival of forest border provenances is endangered due to climate change, small population size, low species competitiveness, etc. Therefore, ancillary measures of population regeneration support are recommended along with broadening of their genetic diversity. Although the knowledge of the levels and structure of genetic diversity of populations is a prerequisite for successful conservation and use, research of this topic regarding Hungarian oak is rare. The analyses of morphological traits of one-year-old seedlings of 40 half-sib families are carried out in order to gain insight into the variability of Hungarian oak population in Lipovica.

The intrapopulation variability was determined based on two measured morphological parameters and one derived ratio. The obtained results show there is a significant variability of morphological traits of seedlings on the level of half-sib families and they indicate a high phenotypic variability of the researched traits. The results of the analysis of variance show statistically significant differences between the researched halfsib families for all observed traits.

The researched gene pool of Hungarian oak is characterized by a satisfactory degree of genetic variability and represents a good starting point for the process of further breeding. In order to confirm the results of this research, i.e., to determine more precisely genetic structure of the population, it is necessary to perform analyses of various phenotypic traits in specially designed field plantations as well as the analysis of adequate DNA markers.
\end{abstract}

Key words: seedlings, variability, gene pool, population.

\footnotetext{
${ }^{1}$ Institute of Forestry, Belgrade, Serbia

${ }^{2}$ PE “Šume-Goč” Vrnjačka Banja, Serbia
} 


\section{VARIJABILNOST SLADUNA (Quercus frainetto Ten.) SA PODRUČJA LIPOVICE PREMA MORFOLOŠKIM SVOJSTVIMA SADNICA}

Izvod: Prirodne populacije sladuna u Srbiji nalaze se blizu severozapadne granice areala ove značajne šumske vrste. Opstanak rubnih provenijencija ugrožen je usled promene klime, male veličine populacija, niske kompetitivnosti vrste i dr. Zbog toga se preporučuju pomoćne mere potpomaganja obnove populacija uz proširivanje njihove genske raznolikosti. Premda je poznavanje nivoa $i$ strukture genetske raznolikosti populacija preduslov uspešne konzervacije $i$ korišćenja, istraživanja ove tematike na sladunu su retka. U cilju upoznavanju varijabilnosti populacije sladuna u Lipovici izvršene su analize morfoloških svojstava jednogodišnjih sadnica 40 linija polusrodnika.

$\mathrm{Na}$ osnovu dva merena morfološka parametara $i$ jednog izvedenog odnosa utvrđena je unutarpopulaciona varijabilnost. Dobijeni rezultati su pokazali postojanje značajne varijabilnosti morfoloških svojstava sadnica na nivou linija polusrodnika $i$ ukazuju na visoku fenotipsku varijabilnost istraživanih svojstava. Rezultati analize varijanse pokazuju statistički značajne razlike između istraživanih linija polusrodnika za sva posmatrana svojstva.

Istraživani genofond sladuna odlikuje se zadovoljavajućim stepenom genetičke varijabilnosti i predstavlja dobru polaznu osnovu za proces daljeg oplemenjivanja. Radi potvrde rezultata ovog istraživanja odnosno preciznije determinacije genetske strukture populacije, neophodno je sprovesti analiza raznovrsnih fenotipskih svojstava u posebno dizajniranim poljskim zasadima kao i analiza prikladnih DNA markera.

Ključne reči: sadnice, varijabilnost, genofond, populacija.

\section{INTRODUCTION}

Hungarian oak (Quercus frainetto Ten.) is an oak species growing in thermophilic deciduous forest in southeastern Europe. Palaeoecological proofs suggest that Hungarian oak was present in Peloponnese more than 6000 years ago (Jahns, 1993). Previous studies of genetic diversity of oak forests have shown that $Q$. frainetto belongs to Dascia section, it is genetically close to $Q$. pubescens and clearly differentiated from Q. robur and Q. petraea (Finkeldey, 2001; Petit et al., 2002; Belletti et al., 2005; Curtu et al., 2007; Fortini et al., 2015). It grows in a wide vegetation belt rich in woody species, mostly in habitats with humid continental climatic conditions, frequent summer droughts, highest amount of precipitation in spring, wide temperature range, low winter temperatures (Horvat et al., 1974). As one of the edificators, Hungarian oak in habitats in Serbia occurs together with Turkey oak in the climatogenic community of Hungarian and Turkey oak Quercetum frainetto-cerridis Rudski 1949. A number of sub-associations representing various ecological variants of Hungarian oak and Turkey oak have been described (Stajić et al., 2008) and several geographic variants within the broadly understood forest of Hungarian oak and Turkey oak (Tomić and Rakonjac, 2013). It is in contact with populated places and agricultural land, so it is under constant pressure, which leads to a gradual reduction of the area of these forests. Due to the anthropogenic influence in the last century, the areas under Hungarian oak forests have been significantly reduced, and that has had a very negative effect 
on its genetic diversity. Natural regeneration of Hungarian oak is very difficult, it is mainly regenerated vegetatively, which additionally affects the reduction of genetic diversity. In addition, in competition with Turkey oak as biologically stronger species, the regeneration of Hungarian oak is insufficient, so it is necessary to fill in the gaps, reestablish its participation in establishing stands or replace it by the reproductive material originated from selected seed sources.

Genetic improvement programs include individual selection of plus trees from the most valuable populations and testing of their offspring in comparative trials at different sites (Wright, 1976). The long-term survival of species is closely related to their genetic diversity (Gapare, 2014). Under the influence of changed environmental conditions, biotic pathogens and damage, the survival and evolution of species depend on the levels of genetic diversity (Reed and Frankham, 2003). Research dealing with genetic diversity and identifying populations with high genetic variability can help reduce the risk of biodiversity loss (Souto et al., 2015). The increase in the adaptability of the species through genetic improvement could greatly increase the ecological, economic and social values of Hungarian oak as well as improve the conservation of this species in its natural habitat (Cetera et al., 2018). In order to create a basis for the preservation of Hungarian oak gene pool and the directed management of available resources, detailed studies of the level, patterns and causes of genetic diversity and structure are necessary.

The aim of the research in this paper was to determine the intrapopulation variability of Hungarian oak according to the morphological traits of one-year-old seedlings. The obtained results can be used for preliminary insight in genetic variability of the researched population, improvement of production of nursery stock and continuation of research on genetic diversity.

\section{MATERIAL AND METHODS}

For the research in this paper acorns were collected from the harvest of 2019, originating from Lipovica Forest Management Unit, of Belgrade Forest Enterprise. Based on phenotypic traits and abundance of yields 40 plus trees evenly distributed on the area of FMU were selected, whereby the minimal distance between the trees was at least $50 \mathrm{~m}$ in order to avoid relatedness. Seeds were collected from trees in order to grow half-sib families where mother is known, but not the other parent, according to the method of genetic analysis of trees (Isajev and Mančić, 2001). Three kilograms of ocularly healthy and undamaged acorns were collected per each tree, regardless of their dimensions. After collection the acorns were dried at $35 \%$ of humidity and stored at a temperature of $3-5{ }^{\circ} \mathrm{C}$. The acorns were sawn in April 2020 separately per plus trees in the nursery of the Institute of Forestry in Belgrade. In uniform environmental conditions, seedlings were produced in a bed measuring $1 \times 40 \mathrm{~m}$. The distance between the rows in a bed is $15 \mathrm{~cm}$ and rows are parallel with the shorter side of the bed.

At the end of the first growing season, root collar diameter and the height of the seedlings were measured on a random sample of 50 seedlings per plus tree and based on the measured values the vigor index according to Roller 1977 was calculated. Root collar diameter was measured by vernier caliper with the accuracy of $0.1 \mathrm{~mm}$, and the height of the seedlings with a ruler, with accuracy of $0.5 \mathrm{~mm}$. 
Morphological traits of the seedlings were described by means of descriptive statistical indicators: arithmetic mean (x), standard deviation (SD), coefficient of variability (CV \%). For the purpose of determining intrapopulation variability the analysis of variance (ANOVA) was used. The analyzed variability factor was a tree. All the above-mentioned statistical analyses were performed using the statistical program STATISTICA 7.0 (StatSoft Inc. 2004).

\section{RESULTS AND DISCUSSION}

Table 1 shows the parameters of descriptive statistics for the researched properties of seedlings.

The mean value of the root collar diameter of the studied half-sib families amounts to $3.7 \mathrm{~mm}$ and ranges from $2.6 \mathrm{~mm}$ (half-sib family 40) to $5.2 \mathrm{~mm}$ (halfsib family 12) with a standard deviation from $0.4 \mathrm{~mm}$ to $1.5 \mathrm{~mm}$. According to the parameter root collar diameter the most homogenous is a half-sib family $5(13.4 \%)$, and the most heterogenous half-sib families are 23 and 27 (36.1\%).

The mean value of seedling height based on the studied half-sib families amounts to $11.4 \mathrm{~cm}$ and ranges from $6.6 \mathrm{~cm}$ (half-sib family 40 ) to $18.5 \mathrm{~cm}$ (halfsib family 1) with a standard deviation ranging from 1.0 to 7.2 . According to the seedling height parameter the most homogenous is a half-sib family 7 (11.8\%), and the most heterogenous half-sib family is $36(57.5 \%)$.

The mean value of the vigor index of the seedlings amounts to 3.1 and ranges from 2.1 (half-sib families 6 and 10) to 4.1 (half-sib family 4) with a standard deviation ranging from 0.3 to 1.8 . According to the parameter vigor index of seedlings the most homogenous is a half-sib family $3(10.6 \%)$, and the most heterogenous is a half-sib family $4(45.4 \%)$.

The most variable trait on the level of the studied half-sib families is a seedling height $(41.3 \%)$, while root collar diameter is the least variable trait $(29.1 \%)$.

Table 1. Descriptive statistics for the measured morphological traits of seedlings

\begin{tabular}{|c|c|c|c|c|c|c|c|c|c|}
\hline \multirow{2}{*}{ Tree } & \multicolumn{3}{|c|}{$\mathbf{d}(\mathbf{m m})$} & \multicolumn{3}{c|}{$\mathbf{h}(\mathbf{m m})$} & \multicolumn{3}{c|}{ h/d } \\
& M & SD & CV & M & SD & CV & M & SD & CV \\
\hline $\mathbf{1}$ & 4.7 & 0.8 & 16.5 & 18.5 & 6.5 & 35.4 & 3.9 & 1.0 & 26.8 \\
\hline $\mathbf{2}$ & 4.9 & 0.9 & 18.4 & 15.8 & 4.4 & 27.7 & 3.3 & 1.0 & 30.7 \\
\hline $\mathbf{3}$ & 4.1 & 0.6 & 15.9 & 13.4 & 2.3 & 17.5 & 3.3 & 0.3 & 10.6 \\
\hline $\mathbf{4}$ & 3.2 & 0.6 & 17.7 & 12.4 & 4.7 & 37.7 & 4.1 & 1.8 & 45.4 \\
\hline $\mathbf{5}$ & 3.0 & 0.4 & 13.4 & 8.4 & 1.7 & 20.4 & 2.9 & 0.7 & 23.0 \\
\hline $\mathbf{6}$ & 4.0 & 1.4 & 34.8 & 8.3 & 2.4 & 28.8 & 2.1 & 0.4 & 18.0 \\
\hline $\mathbf{7}$ & 2.8 & 0.6 & 22.3 & 8.4 & 1.0 & 11.8 & 3.2 & 0.9 & 29.0 \\
\hline $\mathbf{8}$ & 3.6 & 0.9 & 24.4 & 13.7 & 4.7 & 34.2 & 3.8 & 1.1 & 29.4 \\
$\mathbf{9}$ & 4.1 & 0.8 & 20.3 & 12.5 & 2.7 & 21.7 & 3.1 & 0.7 & 21.2 \\
\hline $\mathbf{1 0}$ & 3.6 & 1.0 & 28.0 & 7.5 & 2.5 & 33.6 & 2.1 & 0.4 & 19.8 \\
\hline $\mathbf{1 1}$ & 3.1 & 0.7 & 23.7 & 10.3 & 2.2 & 21.7 & 3.4 & 0.6 & 18.4 \\
\hline $\mathbf{1 2}$ & 5.2 & 1.5 & 29.9 & 17.4 & 5.7 & 33.0 & 3.4 & 0.7 & 21.0 \\
\hline $\mathbf{1 3}$ & 4.1 & 1.0 & 24.9 & 11.6 & 2.7 & 23.3 & 3.0 & 1.0 & 34.7 \\
\hline $\mathbf{1 4}$ & 3.9 & 1.2 & 29.8 & 9.4 & 3.3 & 35.5 & 2.5 & 0.7 & 29.3 \\
\hline $\mathbf{1 5}$ & 3.4 & 1.0 & 29.1 & 10.2 & 3.3 & 32.5 & 3.1 & 0.6 & 20.9 \\
\hline $\mathbf{1 6}$ & 4.4 & 1.4 & 31.8 & 13.8 & 6.0 & 44.0 & 3.2 & 0.9 & 29.3 \\
\hline $\mathbf{1 7}$ & 3.8 & 1.0 & 27.0 & 10.9 & 2.6 & 24.4 & 3.0 & 0.7 & 21.9 \\
\hline
\end{tabular}




\begin{tabular}{|c|c|c|c|c|c|c|c|c|c|}
\hline $\mathbf{1 8}$ & $\mathbf{3 . 5}$ & $\mathbf{1 . 1}$ & $\mathbf{3 1 . 9}$ & $\mathbf{1 0 . 8}$ & $\mathbf{3 . 1}$ & $\mathbf{2 8 . 6}$ & $\mathbf{3 . 1}$ & $\mathbf{0 . 6}$ & $\mathbf{1 7 . 8}$ \\
\hline $\mathbf{1 9}$ & 3.5 & 0.8 & 23.7 & 13.4 & 5.6 & 42.3 & 3.7 & 0.9 & 24.5 \\
\hline $\mathbf{2 0}$ & 3.7 & 0.8 & 20.2 & 11.7 & 2.4 & 20.2 & 3.2 & 0.6 & 18.5 \\
\hline $\mathbf{2 1}$ & 3.9 & 0.8 & 19.4 & 11.0 & 3.3 & 30.2 & 2.9 & 0.8 & 28.2 \\
$\mathbf{2 2}$ & 3.6 & 0.8 & 22.3 & 12.5 & 5.3 & 42.2 & 3.5 & 1.0 & 28.6 \\
\hline $\mathbf{2 3}$ & 4.0 & 1.4 & 36.1 & 11.9 & 2.0 & 16.7 & 3.2 & 0.9 & 28.3 \\
\hline $\mathbf{2 4}$ & 3.6 & 0.7 & 18.7 & 9.1 & 2.5 & 27.9 & 2.6 & 0.6 & 23.4 \\
\hline $\mathbf{2 5}$ & 4.3 & 0.7 & 16.9 & 15.7 & 7.1 & 45.3 & 3.6 & 1.2 & 33.8 \\
\hline $\mathbf{2 6}$ & 3.1 & 0.6 & 20.4 & 8.1 & 2.2 & 27.8 & 2.6 & 0.6 & 24.5 \\
\hline $\mathbf{2 7}$ & 3.7 & 1.3 & 36.1 & 8.7 & 3.5 & 40.1 & 2.4 & 0.5 & 21.2 \\
\hline $\mathbf{2 8}$ & 3.0 & 0.5 & 15.3 & 7.7 & 2.0 & 26.3 & 2.6 & 0.7 & 27.8 \\
\hline $\mathbf{2 9}$ & 4.0 & 0.8 & 19.4 & 12.4 & 5.4 & 43.4 & 3.0 & 1.0 & 32.2 \\
\hline $\mathbf{3 0}$ & 3.4 & 1.2 & 34.6 & 11.2 & 3.0 & 26.6 & 3.5 & 0.6 & 17.6 \\
\hline $\mathbf{3 1}$ & 3.8 & 0.8 & 22.1 & 11.5 & 5.1 & 44.3 & 3.0 & 1.2 & 38.1 \\
\hline $\mathbf{3 2}$ & 4.0 & 1.3 & 32.4 & 13.1 & 7.2 & 54.9 & 3.2 & 0.9 & 27.8 \\
\hline $\mathbf{3 3}$ & 4.1 & 1.2 & 29.8 & 14.7 & 4.9 & 33.4 & 3.7 & 1.3 & 34.2 \\
\hline $\mathbf{3 4}$ & 2.9 & 0.8 & 29.4 & 8.8 & 1.9 & 21.8 & 3.2 & 0.7 & 22.0 \\
\hline $\mathbf{3 5}$ & 3.7 & 1.3 & 35.6 & 11.3 & 4.0 & 35.0 & 3.2 & 1.0 & 32.2 \\
\hline $\mathbf{3 6}$ & 3.3 & 0.8 & 25.6 & 8.9 & 5.1 & 57.5 & 2.6 & 1.0 & 38.0 \\
\hline $\mathbf{3 7}$ & 3.8 & 1.1 & 29.4 & 11.7 & 5.0 & 43.0 & 3.0 & 0.7 & 23.3 \\
\hline $\mathbf{3 8}$ & 4.1 & 1.0 & 24.9 & 14.7 & 4.6 & 31.2 & 3.7 & 0.9 & 23.8 \\
\hline $\mathbf{3 9}$ & 3.5 & 1.0 & 28.0 & 10.3 & 3.6 & 34.8 & 3.0 & 0.6 & 20.5 \\
\hline $\mathbf{4 0}$ & 2.6 & 0.8 & 32.1 & 6.6 & 1.4 & 21.1 & 2.8 & 0.8 & 28.8 \\
\hline Mean & 3.7 & 1.1 & 29.1 & 11.4 & 4.7 & 41.3 & 3.1 & 0.9 & 30.2 \\
\hline
\end{tabular}

Legend: d-root collar diameter; $h$ - seedling height; $h$ /d- height and root collar diameter ratio

Table 2. Analysis of variance for the measured morphological traits of seedlings

\begin{tabular}{|c|c|c|c|c|c|}
\hline Parameter & $\begin{array}{c}\text { SS } \\
\text { Effect }\end{array}$ & $\begin{array}{c}\text { df } \\
\text { Effect }\end{array}$ & $\begin{array}{c}\text { MS } \\
\text { Effect }\end{array}$ & F & p \\
\hline d & 119.077 & 39 & 3.053 & 3.192 & 0.0000 \\
\hline h & 2968.76 & 39 & 76.12 & 4.624 & 0.0000 \\
\hline h/d & 83.162 & 39 & 2.132 & 2.842 & 0.0000 \\
\hline
\end{tabular}

Based on the obtained results of the analysis of variance (ANOVA) it can be concluded that statistically significant differences have been determined between the studied half-sib families for all analyzed morphological traits of seedlings. (Table 2).

The obtained results indicate there is a significant level of phenotypic variability on the level of half-sib families, taking in consideration the researched morphological traits of seedlings. The researched population of Hungarian oak is characterized by a satisfactory degree of genetic variability so it can be used in breeding processes and it is a potential source of a reproductive material of a good quality. Statistically significant differences determined between individual parent trees (genotypes) in the analyses of morphological traits of acorns have also indicated a high level of intrapopulation genetic variability (Popović et al. 2020). For the needs of afforestation and auxiliary measures of natural regeneration of Hungarian oak, acorns are used and seedlings are produced in a generative way, which is why the properties and quality of reproductive material are among the key factors for achieving success in these ventures.

The knowledge on genetic diversity and population structure is the basis for preserving and improving the gene pool of a species. So far, modest research has been done to determine the genetic diversity of Hungarian oak populations in Serbia, so there is a real need for that. The analyses of the amount and distribution 
of genetic variability within and among populations can be used to determine genetic diversity and establish programs for the conservation of genetic resources (Dumolin-Lapegue et al., 1997). The distribution of genetic diversity within and among populations is a function of gene flow rates among populations, and the level of gene flow depends on the spatial distribution of habitats, size and degree of isolation of populations, pollen and seed movements between populations (Bruschi et al. 2003). Great genetic diversity of populations is very important for survival and stability, but in addition, adequate ecological management is necessary for their preservation and in situ conservation (Bruschi et al. 2003). The adaptability of forest tree populations to climate change is largely determined by individual levels of relatedness (Lloret and García, 2016). Uncontrolled use of resources and felling of trees, which result in a decrease in population size, increase the risk of loss of genetic resources and long-term survival of populations (Gilpin and Soule, 1986). In small populations, reduced genetic diversity may be the result of genetic drift, and in subsequent generations, loss of phenomena heterozygosity and inbreeding may lead to reduced condition in these otherwise stable populations (Bruschi et al., 2003). Genetically improved stands and populations with drought tolerance will be highly valued in the future (Apostol et al., 2020).

Based on the performed research, it can be concluded that in the researched population of Hungarian oak there is a high level of variability of the researched morphological traits of seedlings. The obtained results are the basis for the continuation of research that needs to be conducted in order to provide guidelines and recommendations for the conservation and directed use of the genetic resources of Hungarian oak in this population and in the territory of Serbia. For more complete understanding of variability of Hungarian oak in part of its natural range of distribution the research should be continued and broadened using molecular markers and analyses of various phenotypic traits in specially designed experimental plantations.

\section{CONCLUSIONS}

The obtained results provide a preliminary assessment of the genetic variability of the researched plus trees and contribution to the knowledge of the analyzed properties of seedlings and represent a good starting point for future research in species breeding.

On the level of the researched half-sib families the following mean values were obtained: root collar diameter amounts to $3.7 \mathrm{~mm}$ (ranging from 2.6 to 5.2 $\mathrm{mm}$ ), the height of seedlings amounts to $11.4 \mathrm{~cm}$ (ranging from 6.6 to $18.5 \mathrm{~cm}$ ), and vigor index of seedlings amounts to 3.1 (ranging from 2.1 to 4.1).

The occurrence of statistically significant differences for the analyzed morphological traits of seedlings on the level of half-sib families clearly indicates there is a genetic differentiation and high level of intrapopulation variability.

The determined variability of morphological characteristics of one-year-

old seedlings can serve as an indicator of further development of seedlings of selected half-sib families and for improvement of production of Hungarian oak reproductive material of good quality. 
Acknowledgements: This study was carried out under the Agreement on realization and funding of scientific research activity of scientific research organizations in 2021 funded by the Ministry of Education, Science and Technological Development of the Republic of Serbia, No. 451-03-9/2021-14/200027 from February 05, 2021.

\section{REFERENCES}

Apostol, E.N., Stuparu, E., Scarlatescu, V., Budeanu, M. (2020): Testing Hungarian oak (Quercus frainetto Ten.) provenances in Romania, iForest, 13: 9-15.

Belletti, P., Leonardi, S., Monteleone, I., Piovani, P. (2005): Allozyme variation in different species of deciduous oaks from northwestern Italy. Silvae Genetica 54: 9-16.

Bruschi, P, Vendramin, G., Bussotti, F., Grossoni, P. (2003): Morphological and Molecular Diversity Among Italian Populations of Quercus petraea (Fagaceae), Annals of Botany 91: 707-716.

Cetera, P., D’Auria, M., Mecca, M., Todaro, L. (2018): Gallic acid as main product in the water extractives of Quercus frainetto Ten. Natural Product Research 33 (19): 2864-2867.

Curtu, A.L., Gailing, O., Leinemann, L., Finkeldey, R. (2007): Genetic variation and differentiation within a natural community of five Oak species (Quercus spp.). Plant Biology 9: 116-126.

Dumolin-Lapegue, S., DDemesure, B., Fineschi, S., Le Corre, V., Petit, R.J. (1997): Phylogeographic structure of white oaks throughout the European continent. Genetics. Vol. 146: $1475-1487$.

Finkeldey, R. (2001): Genetic variation of oaks (Quercus spp.) in Switzerland. 1. Allelic diversity and differentiation at isozyme gene loci. Forest Genetics 8: 185-195.

Fortini, P., Di Marzio, P., Di Pietro, R. (2015): Differentiation and hybridization of Quercus frainetto, Q. petraea, and $Q$. pubescens (Fagaceae): insights from macromorphological leaf traits and molecular data. Plant Systematics and Evolution 301: 375385.

Gapare, W.J. (2014): Merging applied gene conservation activities with advanced generation breeding initiatives: a case of study of Pinus radiate D. Don. New For. 45: $311-$ 331.

Geburek, T., Konrad, H. (2008): Why the conservation of forest genetic resources has not worked. Conserv. Biol. 22(2): 267-274.

Gilpin, M.E., Soule, M.E. (1986): Minimum viable populations processes of species extinctions. In: Soule ME, ed. Conservation biology: The science of scarcity and diversity. Sunderland: Sinauer, 19-34.

Horvat, L., Glavac, V., Ellemberg, H. (1974): Vegetation Suedosteuropas. Geobot. Selecta 4. G. Fischer, Stuttgart. 
Isajev, V., Mančić, A. (2001): Šumsko semenarstvo, Šumarski fakultet, Univerziteta u Banja Luci, Univerzitet u Beogradu - Šumarski fakultet, Banja Luka, Beograd (1-283). [Isajev, V., Mančić, A. (2001): Forest Seed Production, Faculty of Forestry of the University of Banja Luka, University of Belgrade - Faculty of Forestry, Banja Luka, Belgrade (1-283).]

Jahns, S. (1993): On the Holocene vegetation history of the Argive Plain (Peloponnese, southern Greece) Veget Hist Archaebot 2:187-203.

Lloret, F., García, C. (2016): Inbreeding and neighboring vegetation drive drought induced die off within juniper populations, Functional Ecology, Vol. 30, No. 10: 1696-1704.

Petit, R., Csaikl, U., Bordács, S., Burg, K., Coart, E., Cottrell, J., Van Dam, B., Deans, D., Dumolin-Lapègue, S., Fineschi, S., Finkeldey, R., Gillies, A., Glaz, I., Goicoechea, P.G., Jensen, J.S., König, A.O., Lowe, A.J., Madsen, S.F., Mátyás, G., Munro, R.C., Olalde, M., Pemonge, M.H., Popescu, F., Slade, D., Tabbener, H., Taurchini, D., De Vries, S.G.M., Ziegenhagen, B., Kremer, A. (2002): Chloroplast DNA variation in European white oaks. Phylogeography and patterns of diversity based on data from over 2600 populations. Forest Ecology and Management 156: 5-26.

Popović, V., Lučić, A., Rakonjac, Lj., Jovanović, S., Lazarević, I. (2020): Variability of morphometric characteristics of Hungarian oak (Quercus frainetto Ten.) acorn. Sustainable Forestry, 81-82, 19-28.

Reed, D.H., Frankham, R. (2003): Correlation between fitness and genetic diversity. Conserv. Biol. 17: 230-237.

Roller, K.J. (1977): Suggested minimum standards for containerized seedlings in Nova Scotia. Department of Fisheries and Environment Canada, Canadian Forestry Service, Information Report M-X-69 (1-18)

Souto, C., Mathiasen, P., Acosta, M. (2015): Identifying genetic hotspots by mapping molecular diversity of widespread trees: when commonness matters. J. Hered. 106: 537545 .

Stajić, S., Rakonjac, Lj., Čokeša, V. (2008): Phytocoenological characteristics of Hungarian oak and Turkey oak with hornbeam forest (Carpino betuli-Quercetum farnetto-cerris) in the area of Bogovadja. Sustainable Forestry, 57-58, 104-114.

StatSoft Inc., 2004. STATISTICA, version 7.

Tomić, Z., Rakonjac, Lj. (2013): Šumske fitocenoze Srbije, Institut za šumarstvo Beograd, Univerzitet Singidunum-Fakultet za primenjenu ekologiju Futura, Beograd. [Tomić, Z., Rakonjac, Lj. (2013): Forest phytocoenoses of Serbia, Institute of Forestry Belgrade, Faculty of Applied Ecology Futura of Singidunum University, Belgrade.]

Wright, J.W. (1976): Introduction to forest genetics. Academic Press, New York, USA, pp. 463. 


\title{
VARIABILITY OF HUNGARIAN OAK (Quercus frainetto Ten.) \\ FROM THE TERRITORY OF LIPOVICA ACCORDING TO MORPHOLOGICAL TRAITS OF SEEDLINGS
}

\author{
Vladan POPOVIĆ, Aleksandar LUČIĆ, Ljubinko RAKONJAC, Sanja JOVANOVIĆ, \\ Ivica LAZAREVIĆ
}

\section{Summary}

Hungarian oak (Quercus frainetto Ten.) is an oak species growing in thermophilus deciduous forests in southeastern Europe. Palaeoecological proofs suggest that Hungarian oak was present in Peloponnese more than 6000 years ago. Natural regeneration of Hungarian oak is very difficult, it is mainly regenerated vegetatively, which additionally affects the reduction of genetic diversity. In addition, in competition with Turkey oak as biologically stronger species, the regeneration of Hungarian oak is insufficient, so it is necessary to fill in the gaps, reestablish its participation in establishing stands or replace it by the reproductive material originated from selected seed sources.

The aim of the research in this paper was to determine the intrapopulation variability of Hungarian oak according to the morphological traits of one-year-old seedlings.

For the research in this paper acorns from the harvest of 2019 were used, originating from Lipovica Forest Management Unit, of Belgrade Forest Enterprise, Belgrade. Based on phenotypic characteristics and abundance of yields 40 plus trees evenly distributed on the area of FMU were selected. In the nursery of the Institute of Forestry in Belgrade, in uniform environmental conditions, seedlings were produced separately per plus trees. At the end of the first growing season, root collar diameter and the height of the seedlings were measured on a random sample of 50 seedlings per plus tree and based on the measured values the vigor index was calculated.

Based on the researched half-sib families, the following mean values were obtained: root collar diameter amounted to $3.7 \mathrm{~mm}$ (ranging from 2.6 to $5.2 \mathrm{~mm}$ ), height of seedlings amounted to $11.4 \mathrm{~cm}$ (ranging from 6.6 to $18.5 \mathrm{~cm}$ ), vigor index of seedlings amounted to 3.1 (ranging from 2.1 to 4.1 ).

The results of the analysis of variance (ANOVA) showed that the researched halfsib families differ significantly for all analyzed morphological traits of seedlings, which indicates a high level of intrapopulation genetic variability.

The obtained results contribute to the knowledge on the analyzed traits of seedlings, preliminary assessment of genetic variability of the researched plus trees and represent a good starting point for future research on species breeding, and also can serve for improvement of production of Hungarian oak reproductive material of good quality. 


\title{
VARIJABILNOST SLADUNA (Quercus frainetto Ten.) SA PODRUČJA LIPOVICE PREMA MORFOLOŠKIM SVOJSTVIMA SADNICA
}

\author{
Vladan POPOVIĆ, Aleksandar LUČIĆ, Ljubinko RAKONjAC, Sanja JOVANOVIĆ, \\ Ivica LAZAREVIĆ
}

\section{Rezime}

Sladun (Quercus frainetto Ten.) je vrsta hrasta koja raste u termofilnim listopadnim šumama u jugoistočnoj Evropi. Paleoekološki dokazi sugerišu da je sladun bio prisutan na Peloponezu pre više od 6000 godina. Prirodno obnavljanje sladuna je veoma otežano, uglavnom se obnavlja vegetativnim putem, što dodatno utiče na smanjenje genetičkog diverziteta. Osim toga u konkurenciji cera kao biološki jače vrste, obnavljanje sladuna je nedovoljno, pa je potrebno popunjavanje praznina, ponovno uspostavljanje učešća u izgradnji sastojina ili zamene reproduktivnim materijalom koji potiče iz odabranih semenskih izvora.

Cilj istraživanja u ovom radu bio je da se utvrdi unutarpopulaciona varijabilnost sladuna prema morfološkim svojstvima jednogodišnjih sadnica.

Za istraživanja u ovom radu upotrebljen je žir iz uroda 2019. godine, poreklom iz GJ „Lipovica“, ŠG „Beograd“ Beograd. Na osnovu fenotipskih karakteristika i obilnosti uroda izdvojeno je 40 materinskih stabala ravnomerno raspoređenih po površini gazdinske jedinice. U rasadniku Instituta za šumarstvo u Beogradu, u ujednačenim uslovima sredine proizvedene su sadnice odvojeno po materinskim stablima. Na kraju prvog vegetacionog perioda na slučajnom uzorku od 50 sadnica po materinskom stablu izmereni su prečnik u korenovom vratu, visina sadnica i izračunat je koeficijent jedrine.

$\mathrm{Na}$ nivou istraživanih linija polusrodnika dobijene su sledeće prosečne vrednosti: prečnik u korenovom vratu iznosi 3,7 mm (od 2,6 do 5,2 mm), visina sadnica iznosi 11,4 cm (od 6,6 do 18,5 cm), koeficijent jedrine sadnica iznosi 3,1 (od 2,1 do 4,1).

Rezultati analize varijanse (ANOVA) pokazuju da se istraživane linije polusrodnika statistički značajno razlikuju za sva analizirana morfološka svojstva sadnice što ukazuje na visok nivo unutarpopulacone genetske raznolikosti.

Dobijeni rezultati daju doprinos poznavanju analiziranih svojstava sadnica, preliminarnu procenu genetičke varijabilnosti proučavanih materinskih stabala i predstavljaju dobru polaznu osnovu za buduća istaražiavanja u oplemenjivanju vrste, a mogu poslužiti i za unapređenje proizvodnje kvalitetnog repromaterijala sladuna. 